\title{
INDONESIA'S JUDICIAL REVIEW REGIME IN COMPARATIVE PERSPECTIVE
}

\author{
Theunis Roux* \\ The University of New South Wales (UNSW), Sydney, Australia \\ t.roux@unsw.edu.au
}

\begin{abstract}
This paper provides a comparative perspective on judicial review in Indonesia after the establishment of the Constitutional Court in 2003. It starts by retelling the well-known story of the "transformation of American law" over the first half of the last century. As narrated by Morton Horwitz, that story is about how nineteenth-century industrialisation processes destabilised the premises of "Classical Legal Thought", and then about how the legal realist movement exploited the ensuing crisis to transform the way Americans think about law and its relationship to other social systems. Mining this story for generalisable concepts, the paper argues that the establishment of strong-form judicial review necessarily draws on and, in turn, influences prevailing conceptions of legal and political authority. These conceptions vary along a continuum, in the first case, from public confidence in law's autonomy to a conception of law as deeply immersed in politics, and, in the second case, from a conception of legitimate political authority as contingent on a fairly won democratic mandate to a conception of political authority as residing in the power holder's capacity to promote important social goals, such as national security or economic prosperity. Each of these variables may change independently of the other. In certain situations, however, they may also combine to form a relatively stable judicial review regime - a hegemonic legitimating ideology in which conceptions of legal and political authority lock into and mutually support each other. The fourth section uses this conceptual framework to assess the Indonesian Constitutional Court's approach to its mandate after 2003. Under its first two chief justices, the paper notes, the Court engaged in a concerted effort to build public understanding of its legitimate role in national politics. The Court's abrupt switch between its first Chief Justice, Jimly Asshiddiqie's legalist conception of
\end{abstract}

\footnotetext{
* Professor of Law at The University of New South Wales (UNSW) Sydney, former, Secretary-General of the International Association of Constitutional Law (IACL), and the Founding Director of the South African Institute for Advanced Constitutional, Public, Human Rights and International Law (SAIFAC).
} 
law's authority and his successor, Mohammad Mahfud's more instrumentalist conception, however, has impeded the consolidation of a determinate judicial review regime. Given the considerable threats still confronting Indonesia's democracy, this situation is worrisome. The Court urgently needs to present a coherent account of its legitimate claim to authority if it is to continue playing an effective role.

Keywords: Constitutional Court, Indonesia , Judicial Review, Legal and Political Authority

\section{INTRODUCTION}

Constitutions are seldom written on blank slates. In most cases, they draw on contested societal understandings of a range of issues: the social, political and economic history of the country concerned; the role that past constitutions have played in the regulation of political conflict; the challenges facing the country; the potential role of the constitution in addressing these challenges; and the relevance of foreign constitutional models and experiences. Unless the constitution is imposed from the outside or by authoritarian fiat, these contested understandings will shape the constitutional drafting process. On its enactment, the constitution will come to embody - in general and sometimes ambivalent language - a purportedly shared conception of the legitimate basis for the exercise of political power and the role of the judiciary and other state institutions in controlling the abuse of such power.

To the extent that it validates some ways of thinking about these issues rather than others, a constitution represents a victory of sorts for the ideas it embodies. But such victories are inevitably temporary. As soon as it begins to function, a constitution reinvigorates public discussion of the range of issues just listed, only this time with the text of the constitution as the central reference point. Sometimes, ongoing public discussion may lead to the amendment of the constitutional text to better reflect a new societal understanding of a particular issue or an understanding that an identifiable sub-group has been able to enforce. Even when the constitution is not amended, however, societal understandings of the purposes and value of constitutional government continue to evolve. 
For this reason, it is always advisable to distinguish a society's constitutional tradition from its constitution in the narrower sense of a body of authoritative legal norms governing the allocation of state power. Constitutional traditions underpin and interact with constitutions in this narrower sense, but they are not identical to them. In many societies, the constitutional tradition long predates the current written constitution. While the drafters of the written constitution may have tried to embody that tradition, such attempts rarely succeed completely. In the absence of societal consensus, the constitutional text may fudge some questions to give all the competing elements of a tradition a semblance of victory. Or certain aspects of the tradition may be just too complex to embody perfectly. There will thus always be some tension between the written constitution as adopted and the constitutional tradition it seeks to reflect.

In other cases, the written constitution may have been adopted precisely to transform the country's constitutional tradition, which may be problematic for various reasons. In such cases, an even sharper contrast may develop between the society's constitutional tradition and the text of the written constitution. In some cases, there may be a lag-effect as the new written constitution takes some time to influence the tradition it is trying to transform. In other cases, the written constitution may wholly fail to transform the existing tradition, either because actors slip back into familiar thought-ways and patterns of behaving, or because there was never really any political will to change.

The purpose of this paper is to consider one dimension of this dynamic process and then to apply a general understanding of it to the Indonesian case. Of all the factors making up constitutional traditions, this paper argues, two are particularly important to the comparative study of constitutionalism and judicial review. These are societal understandings, on the one hand, of law's legitimate claim to authority and, on the other, of political authority. What makes those two variables so important is that they are integral to the evolution of constitutional traditions in societies that have adopted so-called 
"strong-form" judicial review ${ }^{1}$ - the most common form of written constitution in the world today. ${ }^{2}$

In giving courts the power to strike down legislative or executive action for non-conformance with their prescriptions, constitutions that provide for strong-form judicial review in theory elevate law to a position of social-systemic equivalence to politics. ${ }^{3}$ They in effect say that law is a social system with its own claim to authority that may in certain cases trump the rival authority claim of politics. The adoption of this form of constitution thus necessarily implicates the society's tradition of thinking about the law/politics relationship in the ongoing process of constitutional development. Of all the different aspects of its constitutional tradition, the one that takes centre stage is the nature of law's claim to authority and its relationship to political authority. If we want to study constitutional development in such a society, therefore, we need to study the way in which societal conceptions of the law/politics relationship shape and are in turn shaped by the institution of judicial review. That aspect of the phenomenon, as partial as it may seem, will be a central part of the drama.

The next section grounds the discussion in a real-world example: the transformation of societal understandings of the law/politics relationship that occurred in the United States over the first half of the last century. This period in American constitutional development is the most widely known instance of this phenomenon while at the same time richly illustrative of its dynamics. The third section extracts the key elements from the American experience that might help to build a comparative framework. The generalisable part of the American experience, this section argues, is the causal significance of

\footnotetext{
The term "strong-form judicial review" was coined in Mark Tushnet, Weak Courts, Strong Rights: Judicial Review and Social Welfare Rights in Comparative Constitutional Law (Princeton, NJ: Princeton University Press, 2008). It refers to situations in which the judiciary has been given the power to review statutes for conformance with the constitution, and to strike down offending parts of a statute. The term "judicial review" will be used in this paper to refer to this specific power. In relation to Indonesia, this means the Constitutional Court's power in Article ${ }_{24} \mathrm{C}(1)$ of the amended 1945 Constitution to review statutes for conformance with the Constitution rather than the Supreme Court's power in Article $24 \mathrm{~A}(1)$ to review ordinances and regulations.

2 By $2006,87 \%$ of world constitutions provided either explicitly or in practice for strong-form judicial review. See David S. Law and Mila Versteeg, "The Evolution and of Global Constitutionalism," California Law Review 99, no. 5 (2011): 1163, 1199.

3 For a longer version of the argument, see Theunis Roux, The Politico-Legal Dynamics of Judicial Review: A Comparative Analysis (New York: Cambridge University Press, 2018).
} 
two factors: (1) the destabilisation of the ideology of so-called "Classical Legal Thought" by the changes to the American economy that occurred in the late nineteenth century; and (2) the opportunistic internal challenge to this ideology mounted by the legal realist movement in the 1920s. Those two factors suggest that settled understandings of the law/politics relationship change when there is some exogenous shock to prevailing conceptions of law's authority and a group of committed legal-cultural actors willing and able to exploit the shock to drive the relevant change. If that is correct, the key to developing a comparative understanding of this phenomenon is to construct a typology of possible stable combinations of legal and political authority and then to use that typology as a heuristic to examine the dynamics of constitutional-cultural change in various settings. The rest of the third section proceeds to classify constitutional traditions into four ideal types according to their distinctive combinations of legal and political authority. The fourth section then uses the conceptual logic underlying these ideal types to reinterpret recent developments in Indonesian constitutional politics. The fifth section concludes.

\section{DISCUSSION}

\subsection{The American Experience}

The discussion has been very abstract so far, so let us ground it in a well-known example of the sort of process this paper seeks to explain: the transformation of societal understandings of the law/politics relationship that occurred in the United States during the first half of the last century. As the story of that period in America's constitutional development is usually told, law's legitimate claim to authority at the beginning of the twentieth century was bound up with the ideology of "Classic Legal Thought". ${ }^{4}$ Law according to that ideology was identified with judge-made common law

\footnotetext{
See Duncan Kennedy, "Toward an Historical Understanding of Legal Consciousness: The Case of Classical Legal Thought in America, 1850-1940," Research in Law and Sociology 3 (1980): 3; Robert W. Gordon, "Legal Thought and Legal Practice in the Age of American Enterprise, 1870-1920," in Professions and Professional Ideologies in America, ed. Gerald L Geison (Chapel Hill: University of North Carolina Press, 1983), 70; Morton J. Horwitz, The Transformation of American Law, 1870-1960: The Crisis of Legal Orthodoxy (New York: Oxford University Press, 1992).
} 
and was thought to consist of a coherent body of norms that was relatively autonomous from politics. The role of legal academics, as famously explained by Dean Christopher Columbus Langdell at Harvard University, ${ }^{5}$ was to rationalise this body of norms so that every case decided by a court could be assessed according to its conformance to applicable legal principles. Judges in turn were legal technicians, and their claim to authority lay in their perceived professionalism and detachment from politics.

This understanding of law's claim to authority steadily changed from 1900 , both in response to external forces and in response to endogenous challenges. ${ }^{6}$ Externally, the American economy had been developing over the second half of the nineteenth century from a mainly agricultural economy into an industrialized one. ${ }^{7}$ Accompanying this change, there had been a massive population influx to new urban centres like New York and Chicago. The conditions of employment in these new centres were harsh and living arrangements unhealthy. ${ }^{8}$ In response, state legislatures began to enact minimum wage laws and other social welfare legislation. ${ }^{9}$ The new laws constituted an attempt to expand the scope of the state legislatures' authority. Before 1900, the ideology of laissez-faire, the economic counterpart to Classical Legal Thought, had held that private economic relations were strictly off-limits to state legislatures - an aspect of social life governed by the politically autonomous common law of contract. As a matter of constitutional law, this understanding of the law/politics relationship had been concretised in the so-called "police power" doctrine, which held that state legislatures could intrude into the market only to protect public health, safety and morals...$^{10}$ Thus, when state legislatures began enacting social welfare legislation, they were initially perceived as intruding into areas beyond the legitimate scope of their authority.

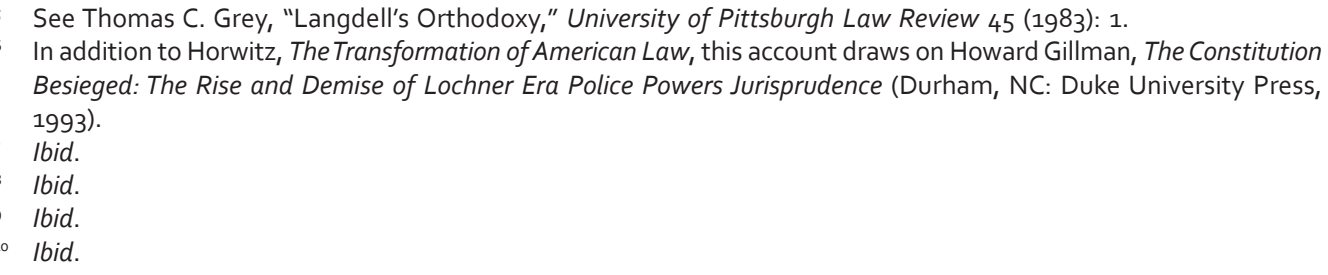


The conflict over state legislatures' attempt to expand the scope of their authority famously came to a head in the case of Lochner v. New York ${ }^{\text {n }}$ and then continued in a series of cases decided by the US Supreme Court between 1905 and 1937. ${ }^{12}$ In Lochner, the Supreme Court decided that a maximum working hours law for bakers was unconstitutional against the Fourteenth Amendment's due process clause. The decision was roundly criticised by Justice Oliver Wendell Holmes in dissent and by academic commentators as a political decision driven by the justices' support for an outdated laissez-faire ideology that it was in any case not their role to enforce from the Bench. ${ }^{33}$ In substantive content, however, the majority decision was a straightforward application of the police power doctrine. ${ }^{14}$ To be sure, it was an open legal question whether the maximum working hours legislation at issue could be said to have been enacted in pursuit of public health, safety or morals (as opposed to the private interests of the bakers qua employees), but the Supreme Court's approach to this question followed a line of reasoning that was pretty standard at the time. In that sense, it was a legally legitimate decision - well within the scope of the Court's authority as it was then understood. What caused the controversy in Lochner was not the fact that the case was obviously wrongly decided, but that it came at a time when the abovementioned changes to the American economy were beginning to destabilise the premises of Classical Legal Thought. What had hitherto been a stable relationship between the common law's claim to authority over the regulation of private economic matters and state legislatures' claim to authority over any social problem falling within their democratic mandate, began to collapse.

At roughly the same time as the Lochner line of cases was playing itself out, a group of prominent American legal academics mounted an internal challenge to the premises of Classical Legal Thought. Inspired by

${ }_{11}$ Lochner v. New York 198 US 45 (1905).

12 The end of the era is marked by the Court's decision is West Coast Hotel v. Parrish 300 US 379 (1937) (when Justice Roberts famously "switched" his vote to favour the constitutionality of New Deal legislation).

13 See Lochner v. New York (Holmes J dissent).

${ }_{14}$ See Gillman, The Constitution Besieged. 
the German Freirechtsschule, ${ }^{15}$ Roscoe Pound and others began critiquing the idea that judges were operators of a technical legal machine. ${ }^{16}$ On the contrary, Pound argued, the law was often indeterminate, and judges were then essentially in the position of having to decide between competing social interests without any authoritative guidance. To do justice in that situation, judges had to resort to social science - to the best knowledge available about which of several competing legal rules would best promote the public interest. ${ }^{17}$ In arguing thus, Pound seized on the Supreme Court's decision in Lochner as a classic instance of "mechanical jurisprudence" - an implausible attempt to deduce the legal content of freedom of contract from the semantic scope of the word "liberty" in the Fourteenth Amendment. In fact, as noted, the Supreme Court's decision in Lochner was based on a settled line of precedent. ${ }^{18}$ It was not particularly formalist in the way Pound made it out to be. Nevertheless, Pound was able to capitalise on the decision's unpopularity to use it as ammunition in his attack on Classical Legal Thought.

Though he later famously fell out with Karl Llewellyn, ${ }^{19}$ Pound is today regarded as someone whose ideas and thinking paved the way for legal realism - the jurisprudential movement that gained a foothold in several prominent American law schools in the 1920s and 1930s and forever changed the way American lawyers, and the American public more broadly, think about law's claim to authority. The full story of the rise of the legal realist movement and its impact on American legal thought is contested and too complicated to summarise here. ${ }^{20}$ At its heart, however, was a critique of

\footnotetext{
See Albert S. Foulkes, "On the German Free Law School (Freirechtsschule)," Archiv für Rechts- und Sozialphilosophie /Archives for Philosophy of Law and Social Philosophy 55 no. 3 (1969): 367; Kristoffel Grechenig and Martin Gelter, "The Transatlantic Divergence in Legal Thought: American Law and Economics vs. German Doctrinalism," Hastings International and Comparative Law Review 31 no. 1 (2008): 295.

16 Roscoe Pound, "Mechanical Jurisprudence," Columbia Law Review 8 (1908): 605.

17 Ibid.

18 Gillman, The Constitution Besieged.

19 See William Twining, Karl Llewellyn and the Realist Movement zed. (Cambridge, Cambridge University Press, 2012).

20 See, for example, Horwitz, The Transformation of American Law; Brian Z. Tamanaha, Beyond the FormalistRealist Divide: The Role of Politics in Judging (Princeton, NJ: Princeton University Press, 2010); Frederick Schaver, "Foreword," in William Twining, Karl Llewellyn and the Realist Movement 2ed. (Cambridge, Cambridge University Press, 2012), ix.
} 
the determinacy of law and legal reasoning, and a positive programme, drawing on Pound's insights, of fixing that problem by resort to social science. The philosophical writings of John Dewey also exerted a strong intellectual influence on the movement, ${ }^{21}$ so that it is has been depicted as changing the American view of law to one of "pragmatic instrumentalism". ${ }^{22}$

For purposes of this article, the significant issue is that, in a complex interaction between the changes to the American economy just described, the controversy over the Lochner line of cases, and the sometimes quite opportunistic arguments of legal realism, societal understandings of law's claim to authority in the US progressively changed from 1900 through 1937. Whereas law's claim to authority before the turn of the twentieth century had been premised on its assumed autonomy from politics, after 1937 its authority was increasingly based on its instrumental value in promoting concededly partisan-political visions of the public interest and social welfare.

The story of the evolution of the American "judicial review regime" - the complex of legitimating ideas that make up the hegemonic understanding of the law/politics relationship in the US - is still unfolding, as most recently illustrated in the ructions over Brett Kavanaugh's Senate confirmation hearing. As it functions today, the regime is one in which the US Constitution is seen as standing for two competing, even diametrically opposed visions of the just society - one based on conservative and the other on liberal values. In addition to the factors already mentioned, this has occurred because the outdated text of the US Constitution has proved malleable enough to allow generations of conservative and liberal judges to plausibly claim that their preferred political ideology corresponds to the true American constitutional project. ${ }^{23}$ While each side of politics thus presents its interpretation of the Constitution as a precedent-based legal interpretation, the dominant societal understanding is that the Constitution

${ }^{21}$ See Robert S. Summers, "Pragmatic Instrumentalism in Twentieth Century American Legal Thought - A Synthesis and Critique of our Dominant General Theory about Law and its Use," Cornell Law Review 66 (1981): 861; Richard A. Posner, "What Has Pragmatism to Offer Law?" Southern California Law Review 63 (1990): 1653.

22 Summers, "Pragmatic Instrumentalism".

23 Duncan Kennedy, A Critique of Adjudication (Fin de Siècle) (Cambridge, MA: Harvard University Press, 1997). 
has two equally plausible interpretations, each of which is determinate according to its ideological premises. ${ }^{24}$ The stability of this judicial review regime, such as it is, comes from the fact that political power regularly rotates through democratic elections, meaning that each side of politics is eventually given the opportunity to appoint a sufficient number of Supreme Court justices to transform its political ideology into constitutional law.

Now that we have illustrated the abstract idea of the evolution of judicial review regimes with a practical example, can we generalise it? Are there recurrent patterns in the way societal understandings of the law/politics relation change character over time that might help us to reinterpret wellknown constitutional developments in other societies?

\subsection{Generalising the American Experience}

Consider again what happened in the US during the first half of the last century. An external development - the transformation of the American economy - forced a change in the scope of the state legislatures' claim to political authority. Whereas before 1900, the scope of that authority had not extended to regulating the conditions of employment in the new cities and other aspects of social welfare, changing economic conditions prompted state electorates to demand action on that front. In enacting the new social welfare legislation, state legislatures began intruding into what was previously thought to be the exclusive domain of law's authority - private economic relations as governed by the common law of contract.

It is important to be precise at this point. The basic form of the state legislatures' claim to political authority had not changed. As before, their authority extended to whatever social issues democratic electorates had given them a mandate to regulate. What had changed, was the scope of that claim in its extension to social welfare legislation and its consequent intrusion into areas previously thought to be reserved to the common law

24 James L. Gibson and Gregory Caldeira, "Has Legal Realism Damaged the Legitimacy of the U.S. Supreme Court?" Law \& Society Review 45, no. 1 (2011): 195 (finding, on the basis of extensive social surveys, that the American public understands that constitutional adjudication is driven by the justices' political ideologies but accepting nevertheless that they have principled resort to those ideologies when deciding cases). 
of contract. The external development, America's changing economy, had driven a change in the scope of the state legislature's political authority and brought it into conflict with extant understandings of the scope of law's authority. That conflict in turn caused a rupture in the premises of Classical Legal Thought that the legal realist movement was able to exploit. In sometimes opportunistic ways, legal realists drove a new understanding of law's authority as contingent, not on its autonomy from politics, but on law's usefulness as an instrument for the pursuit of political goals. This new understanding progressively locked into extant understandings of political authority as deriving from a democratic mandate to form a new judicial review regime. The key concepts are thus: societal understandings of law's legitimate claim to authority and its relationship to legitimate political authority, the capacity of these two forms of authority mutually to support each other in a stable judicial review regime, the possibility of an exogenous shock to that regime, and the role of legal-cultural actors in driving a transition to a new regime. These are the elements of the American experience that provide the building blocks for a comparative framework.

In constructing such a framework, the obvious place to start is with the idea of claims to legal and political authority. Neither law nor politics makes claims, of course; both are just abstract concepts whereas constitutional politics is about real people with real interests. Nevertheless, we can use the idea of legal and political authority claims as a kind of shorthand for what happens when social actors make claims to authority in the name of law or politics. A judge handing down a decision thus claims the authority to do that as a duly mandated interpreter of the constitution, say, while parliamentarians enacting legislation rely on the authority of their democratic mandate, and so on.

In each case, the claim needs to be legitimated. Until that happens, a claim is just a claim: it is in competition with other claims to authority to regulate the same conduct or distribute the same material resources. What then legitimates claims to legal or political authority? One answer is 
to see such claims as being legitimated by their conformance to dominant societal understandings of the appropriate relationship between law and politics. These understandings, as we have seen, are an aspect of a society's constitutional tradition. In countries that have adopted a system of supremelaw judicial review, legal and political actors draw on them when they engage in constitutional politics. Even before this, constitutional drafters are influenced by societal understandings of the law/politics relationship when deciding the nature and scope of authority to be conferred on various institutions.

As an aspect of its constitutional tradition, societal understandings of the law/politics relationship are specific to each country. Constitutional traditions are autochthonous and expressive - deeply revealing of the unique political history of the country with which they are associated. Once consolidated, each country will have its own ever-evolving judicial review regime in that sense - a hegemonic societal understanding of the law/politics relationship like the one that prevailed in the US before 190o. Nevertheless, for comparative purposes, it is possible to identify a more limited number of judicial review regimes using a sociological research strategy made famous by Max Weber. ${ }^{25}$ The strategy proceeds by distinguishing the two main ways in which claims to legal and political authority are typically made and then by combining those conceptual possibilities into four ideal types.

Drawing again on the American experience, the two main conceptions of law's claim to authority that may be distinguished are legalism and instrumentalism. Both these conceptions have deep roots in Anglo-American legal theory, but also in other jurisprudential traditions, including the German. ${ }^{26}$ On a legalist conception, law's authority lies in its autonomy as a social system. In practical terms, this is expressed as a dominant legalcultural ideology rather than an empirically provable fact. The core tenet of legalism is that methods of legal reasoning provide politically impartial

25 Max Weber, Economy and Society, ed. Günther Roth and Claus Wittich (New York: Bedminister Press, 1968).

26 They roughly correspond, for example, to Weber's notion of formal and substantive rationality (ibid). 
ways for judges to decide cases. It is not necessary for the maintenance of this ideology that these decisions should be seen to be uniquely correct, provided that the methods judges use are seen to be capable of excluding the influence of political factors, such as the judges' personal world views or their partisan political loyalties. There is a complex interaction between the development of these legal reasoning methods and public confidence in law's autonomy, ${ }^{27}$ but for now we can leave it at that.

Certain countries develop this faith in law's autonomy only to lose it. This is what happened in the US during the Lochner era. As we have seen, in a complex interplay between the Supreme Court's increasingly strained interpretation of the Fourteenth Amendment, the legal realists' assault on the determinacy of law, and the rise of pragmatism as the dominant societal philosophy, Americans lost their faith in law's capacity to exclude ideological attitudes from legal reasoning processes. In legal academia, this was reflected in a turn to social science. If law itself could not provide determinate answers to legal questions from within its own immanent logic, then the study of legal doctrine was pointless. Legal academics instead should take up social science so that they could provide reliable guidance on law's likely consequences. In legal practice, the loss of faith in law's autonomy was similarly reflected in a shift towards consequentialist reasoning. In a dispute over which of two legal rules should apply, the semantic scope of the rules and their fit with extant legal principles became less important than their provable social consequences. ${ }^{28}$

This new American way of seeing law's authority is aptly described as instrumentalist: law's authority derives not from its claimed political neutrality but from the desirability of the outcomes it produces. The US is not the only country whose judicial review regime has undergone such a transformation. A similar process occurred in India after the 1975-1977

\footnotetext{
See section 4 below.

28 See Patrick S. Atiyah and Robert S. Summers, Form and Substance in Anglo-American Law: A Comparative Study of Legal Reasoning, Legal Theory, and Legal Institutions (Oxford: Clarendon Press, 1987).
} 
Emergency. ${ }^{29}$ In that country, the Supreme Court's poor performance during the Emergency discredited legalism and paved the way for a new understanding of the Indian Constitution as an instrument for uplifting the poor and other marginalised groups..$^{30}$

Instrumentalism also tends to be the dominant conception of law's authority in societies in which law has never established its autonomy from politics - where law is seen, and always has been seen, as a mere projection of political power. In societies like that, law's claim to authority is derivative in the sense that it is only as strong as the authority claim of the political power holder that enlists law in service to its ends. This makes law's claim to authority in such societies seem like law's claim to authority in democratic societies that have lost their faith in law's autonomy. Instrumentalism in such societies, however, is crucially different from instrumentalism in democratic societies. In the latter instance, the existence of a functioning democratic system means that there are always at least two competing visions of the just society that law is enlisted to serve. Political parties' claim to authority is in turn legitimated by the authenticity of their democratic mandates, in this way lending democratic legitimacy to law's claim to authority.

Claims to political authority may likewise be divided into two main variants. According to the first, political authority derives from the authenticity of a democratic mandate. No political party may wield power unless it can point to a democratic mandate received in consequence of a free and fair election. In the other main variant, political authority derives from some or other societal goal that the political power holder claims to be promoting, whether that be inter-ethnic harmony, economic prosperity, national security, or the furtherance of anti-colonial revolutionary tradition. ${ }^{31}$ In societies where this second view of political authority prevails, democratic elections may play some role in legitimating political authority, but in the

29 See Upendra Baxi, The Indian Supreme Court and Politics (Lucknow: Eastern Book Co, 1980).

30 For a compelling recent account of this process, see Anuj Bhuwania, Courting the People: Public Interest Litigation in Post-Emergency India (Cambridge: Cambridge University Press, 2017).

${ }^{31}$ Singapore is a good example of this type of society. See Jothie Rajah, Authoritarian Rule of Law: Legislation, Discourse and Legitimacy in Singapore (New York: Cambridge University Press, 2012). 
end, when the principle of democracy and the political power holder's interests come into conflict, the power holder's claim to be promoting some superior conception of the national interest trumps the need to respect the democratic system - and political opponents' views and activities are suppressed in the name of the political power holder's pursuit of that supposedly more important social goal.

At a conceptual level, therefore, we have two main variants of each type of authority claim. Both variants of each type may in theory combine with either variant of the other type, meaning that there are four possible combinations, as depicted in the following table:

Table 1: Typology of Judicial Review Regimes

\begin{tabular}{|c|c|c|}
\hline & $\begin{array}{c}\text { Political authority } \\
\text { based on a mandate } \\
\text { derived from a fully } \\
\text { competitive democratic } \\
\text { system that respects } \\
\text { liberal political rights }\end{array}$ & $\begin{array}{c}\text { Political authority } \\
\text { based on asserted need } \\
\text { to subordinate the } \\
\text { democratic system to } \\
\text { some overarching and } \\
\text { democratically non- } \\
\text { negotiable conception } \\
\text { of the public interest }\end{array}$ \\
\hline $\begin{array}{c}\text { Law's authority based } \\
\text { on public confidence } \\
\text { in the autonomy of law } \\
\text { from politics }\end{array}$ & Democratic Legalism & Authoritarian Legalism \\
\hline $\begin{array}{c}\text { Law's authority based } \\
\text { on its perceived } \\
\text { usefulness as an } \\
\text { instrument for the } \\
\text { pursuit of political } \\
\text { goals }\end{array}$ & $\begin{array}{c}\text { Democratic } \\
\text { Instrumentalism }\end{array}$ & $\begin{array}{c}\text { Authoritarian } \\
\text { Instrumentalism }\end{array}$ \\
\hline
\end{tabular}

As noted, the assumption underlying Table 1 is that either variant of legal authority may lock into either variant of political authority to produce a relatively stable understanding of the appropriate relationship between 
law and politics. An example of the social process through which this might occur is given in the discussion of the Indonesian case in section 4 below. For the moment, the discussion turns to the mutual legitimation logic that binds each of these regimes together. ${ }^{32}$

Under the first ideal type, democratic legalism, law's authority is founded on the claimed capacity of legal reasoning methods to exclude the influence of judges' personal political values and partisan political commitments on judicial decision-making. This understanding of law's authority is paired with a conception of political authority as stemming from a democratic mandate received under conditions of free and fair political competition. Once consolidated, the ongoing stability of this type of regime depends on the judiciary's observance of the reasoning methods that have come to be associated with the ideal of law's autonomy from politics. Provided the judiciary is seen as staying within these limits, or develops these reasoning methods only incrementally, its power of judicial review is respected. More than this, judicial review serves an important legitimating function in the construction of political authority. Judicial review fulfils this function, first, by authenticating electoral mandates as the product of a fair and competitive democratic process, and secondly, by legitimating those laws and executive acts that are not struck down for lack of conformance to the Constitution. ${ }^{33}$

Authoritarian legalism, by contrast, describes a situation in which a public commitment to the separability of law and politics functions, not as the legitimate basis on which law speaks truth to political power, but as a pretext for certain areas of social life to be put beyond the reach of law. ${ }^{34}$ In such regimes, judicial review continues to operate, and may in

32 The following exposition of the four ideal types is reproduced from Roux, The Politico-Legal Dynamics of Judicial Review.

33 Cf. David M. Trubek, "Complexity and Contradiction in the Legal Order: Balbus and the Challenge of Critical Social Thought about Law," Law \& Society Review 11 (Winter 1977): 529, 540 (the "neutrality and autonomy of law forms one basis for the claims of political systems in capitalist societies to legitimate authority" (citing Weber, Economy and Society, 941-54)).

34 Cf. Terence C. Halliday and Lucien Karpik, "Political Liberalism in the British Post-Colony: A Theme with Three Variations," in Fates of Political Liberalism in the British Post-Colony: The Politics of the Legal Complex, ed. Terence C. Halliday, Lucien Karpik and Malcolm Feeley (Cambridge, Cambridge University Press, 2012), 3, 15 (analysing the path of "despotic order" in British post-colonial states). 
fact flourish in certain areas, but is ineffective in the crucial sense that it provides few resources for proponents of a more open and competitive democratic system to challenge authoritarian power holders. While not necessarily dispensing with the holding of elections, power holders' claim to authority in authoritarian legalist regimes rests on some alternative basis, such as the preservation of ethnic harmony, the promotion of economic prosperity or the provision of security from some or other external threat. The stability of this regime comes from the residual legitimating role that law continues to play in these circumstances, together with power holders' skill in prosecuting their alternative, less than fully democratic claim to authority.

Authoritarian instrumentalism describes a situation where law operates as a mere instrument of authoritarian rule, and where law is thus not autonomous from politics in any meaningful sense. Here, stability is a function of naked force and non-legal forms of legitimation, with law acting as a projection of political power rather than a constraint on it. Law has no legitimating role in such regimes. Because there are virtually no significant areas of social life over which judges exert independent control, law's claim to being autonomous from politics has no credibility. In such regimes, law really does function as a subsystem of politics in the sense that it is a fully subordinated system with no autonomous capacity to thwart or even significantly regulate the abuse of political power. While judicial review formally exists, it functions neither to legitimate nor to check political power. Rather, judicial review serves a series of purely instrumental functions, such as the extension of central political control over regional areas, the provision of information to central power-holders, and the transmission and implementation of centralized political commands. ${ }^{35}$

\footnotetext{
See Tamir Moustafa and Tom Ginsburg "Introduction: The Functions of Courts in Authoritarian Politics," in Rule by Law: The Politics of Courts in Authoritarian Regimes, ed. Tom Ginsburg and Tamir Moustafa (New York, Cambridge University Press, 2008) 4-11; Martin Shapiro, Courts: A Comparative and Political Analysis (Chicago: University of Chicago Press, 1986).
} 
The final ideal type, democratic instrumentalism, brings us back full circle to a relatively stable understanding of the relationship between law and politics that arises where political authority is founded on the authenticity of a democratic mandate. As with democratic legalism, no political party is able to compete for, let alone hold, political power in such a regime without expressing its commitment to multiparty democracy, and all major political players accept that they must relinquish power if defeated in a democratic election. (This does not mean that the democratic system actually is free from corruption and the influence of moneyed interests. It simply means that all parties are outwardly committed to the principle of free and fair elections.) What distinguishes this type of judicial review regime from democratic legalism is that law's authority is premised, not on the strenuous denial of the irreducibly political nature of constitutional adjudication, but on the frank embrace, or at least grudging acceptance, of this fact. In place of the denial of law's politicality, law's authority is premised on its claimed capacity to promote substantively just outcomes and on decision-makers' candour about the politics of constitutional adjudication, which is dealt with by foregrounding rather than suppressing the value-laden choices that are being made.

\subsection{Indonesia: In Search of a Determinate Judicial Review Regime}

The four judicial review regimes just presented are conceptual constructs - theoretically possible ways in which claims to legal and political authority may reinforce each other in a stable legitimating ideology. Actually-existing judicial review regimes do not conform exactly to these ideal types. Indeed, as soon as one considers real-world examples, it is apparent that in every society that has adopted a system of strong-form judicial review there is a unique and constantly evolving set of societal understandings of legal and political authority. Nevertheless, the idea of judicial review regimes may be used to explain periods of relative stability in the evolution of these understandings - periods, that is, where claims to legal and political authority, even as they conflict in the daily business of constitutional 
politics, support each other at some deeper level. The conceptual framework in section 2.2 may also be used to understand the social process through which actually-existing judicial review regimes come to stabilize. The rest of this section illustrates these points by using the framework to analyse the evolution of conceptions of legal and political authority in Indonesia after the establishment of a constitutional court with the power of strongform judicial review in 2003.

The first thing to emphasize is that the decision to provide for strongform judicial review in Article 24C(1) of the amended 1945 Constitution was not the product of a conscious decision to elevate law to a position of co-equal status with politics. As with most real-world constitutional reform processes, Indonesia's path to judicial review was marked by political bargaining in circumstances of limited information about how the institutions being created would function in practice. ${ }^{36}$ On one view, the establishment of judicial review came about as a side-effect of the pursuit of other political goals. The "proximate cause" of the creation of the Constitutional Court, on this understanding, was the need for an impartial institution to oversee the presidential impeachment process. ${ }^{37}$ Once the decision to create a Court for that reason had been taken, additional responsibilities were conferred on it, including the power to review statutes for conformance with the Constitution..$^{38}$ On another view, the establishment of judicial review was the fulfilment of a long-standing demand for negara hukum (the rule of law) that had been consistently voiced in previous (failed) liberal constitutional reform processes. ${ }^{39}$ Even on this understanding, however, it is fair to say that the full implications of giving the Constitutional Court the power of

${ }^{36}$ See Donald L. Horowitz, Constitutional Change and Democracy in Indonesia (Cambridge, Cambridge University Press, 2013); Fritz Edward Siregar, "Indonesian Constitutional Politics: 2003-2013" (Doctoral dissertation., UNSW Sydney, 2016), 123; Simon Butt, The Constitutional Court and Democracy in Indonesia (Leiden: Brill Nijhoff, 2015), 11-13; Stefanus Hendrianto, Law and Politics of Constitutional Courts: Indonesia and the Search for Judicial Heroes (London, Routledge, 2018), 41 (describing the establishment of the Court as a "joke that turned serious").

37 Hendrianto, Law and Politics of Constitutional Courts, 52.

38 lbid.

39 Butt, The Constitutional Court and Democracy, 19-32; Daniel S. Lev, "Judicial Authority and the Struggle for an Indonesian Rechtsstaat," Law \& Society Review 13 no. 1 (Autumn 1978): 37. 
judicial review were not fully appreciated..$^{40}$ Rather, it was left to the first group of judges to spell them out - to translate the Constitution's promise of independent judicial review into a functioning institution.

This somewhat uncertain start, along with other factors, ${ }^{41}$ has complicated the consolidation of a determinate judicial review regime in Indonesia. Had there been a clearer understanding of the full implications of the institution that was being created, the path to consolidation would undoubtedly have been smoother. Making matters worse, the Court's first two chief justices, Jimly Asshiddiqie and Mohammad Mahfud, promoted equally valid, but very different, understandings of law's legitimate claim to authority - the first discernibly legalist in flavour and the second more instrumentalist. The Court's alternation between those two understandings has further delayed the consolidation of a determinate judicial review regime.

That the 1999-2002 constitutional reform process called for a revised conception of the law/politics relationship in Indonesia is beyond dispute. The amended 1945 Constitution's provision for free and fair elections and multi-party political competition clearly signalled a fundamental change to the nature of political authority. Both President Soekarno's Guided Democracy and the New Order regime of President Soeharto had built their claim to legitimacy on a combination of charismatic leadership and the asserted need to unify the nation in the turbulent Cold War period. ${ }^{42}$ With Soeharto's departure in 1998, the constitutional reform process marked a decisive shift towards an understanding of legitimate political authority as contingent on a democratic mandate. Although still under periodic threat from authoritarian elements, ${ }^{43}$ Indonesia has maintained a steady commitment to that understanding ever since. ${ }^{44}$ At the same time,

40 Hendrianto, Law and Politics of Constitutional Courts, 77.

${ }_{41}$ These other factors, to list them in one place, include the damage done to law's authority under previous authoritarian administrations, and particularly that of President Soeharto; Indonesia's civil-law tradition, which supports a judicial reasoning style that is arguably not conducive to the sort of role the Constitutional Court has been asked to play; and the various corruption scandals that have afflicted the Court over the years.

42 Butt, The Constitutional Court and Democracy, 21-24; Hendrianto, Law and Politics of Constitutional Courts, 43.

43 See Marcus Mietzner, "How Jokowi Won and Democracy Survived," Journal of Democracy 25, no. 4 (2014): 111.

44 https://freedomhouse.org/report/freedom-world/2017/indonesia. 
there have been sustained attempts to rebuild the independence of the judiciary. ${ }^{45}$ Law now plays a crucial role in holding political office bearers to account, and the courts and other institutions are extensively involved in monitoring the fairness of the electoral process. ${ }^{46}$ It is thus beyond dispute that Indonesia has decisively broken with past authoritarian understandings of the law/politics relationship. What is less clear, however, is what kind of judicial review regime Indonesia is moving towards.

This kind of uncertainty is not unusual, it should immediately be said, for a country in Indonesia's situation. Comparative experience shows that, in the wake of profound constitutional changes of the kind that Indonesia has undergone, a new hegemonic conception of the appropriate relationship between law and politics may take some time to stabilize. ${ }^{47}$ In Hungary, for example, the amendments to its 1989 Constitution have failed to drive the anticipated transition to democratic legalism, despite the best efforts of an initially powerful Constitutional Court..$^{8}$ As things stand, Hungary is slipping back into a type of authoritarian legalism based on its preCommunist, ethno-nationalist tradition. ${ }^{49}$ In Zimbabwe, too, neither its 1979 nor its 2013 Constitution has been able to break the stranglehold of its historically dominant authoritarian-legalist regime..$^{50}$

In Indonesia's case, the task of articulating the amended 1945 Constitution's conception of the law/politics relationship initially fell to the first Bench of the Constitutional Court, and particularly to its first Chief Justice, Jimly Asshiddiqie. Asshiddiqie, everyone agrees, ${ }^{51}$ was acutely aware of the enormity of the responsibility that had been thrust upon him.

45 See Butt, The Constitutional Court and Democracy, 20-21. The story of President Soeharto's assault on the Supreme Court is told in Sebastiaan Pompe, The Indonesian Supreme Court: A Study of Institutional Collapse (Ithaca, NY: Cornell Southeast Asia Program Publications, 2005).

46 Butt, The Constitutional Court and Democracy, 147-290.

47 See Roux, The Politico-Legal Dynamics of Judicial Review, 269-280.

The Hungarian Constitutional Court under its first President, László Sólyom.

Miklós Bánkuti, Gábor Halmai and Kim Lane Scheppele, "Hungary's Illiberal Turn: Disabling the Constitution," Journal of Democracy 23, no. 3 (2012): 138.

See Roux, The Politico-Legal Dynamics of Judicial Review, 193-241.

${ }^{1}$ Hendrianto, Law and Politics of Constitutional Courts; Butt, The Constitutional Court and Democracy; Siregar, Indonesian Constitutional Politics. 
Appreciating that the Constitution's promise that law would enjoy a status co-equal with politics could not simply be taken for granted, he insisted that the Constitutional Court should be accommodated in a fashion worthy of the role it had been asked to perform. ${ }^{22}$ The Court's imposing GraecoRoman building, with its nine pillars and central location in Jakarta, has done much to ensure that its decisions are taken seriously. ${ }^{53}$ In addition to this, the Court under Asshiddiqie's chief justiceship worked hard to develop consistent standards, both for the holding of judicial conferences and for what was expected of judges when writing their opinions. ${ }^{54}$ The Court also took proactive steps to explain its institutional role to the Indonesian public. ${ }^{55}$

Judging by the nature of these initial steps, it is fair to say that Asshiddiqie set about building a legalist understanding of the Court's authority. One of the things Asshiddiqie did, for example, was to establish a new practice of reasoned opinion-writing that departed from the declaratory style associated with Indonesia's civil law tradition. ${ }^{56} \mathrm{He}$ also encouraged the writing of dissents, thus presenting the decision-making process as one in which judges strive to give their own good-faith account of the law. ${ }^{57}$ At the same time, the first Bench's remedial orders were generally non-intrusive - a species of weak-from review..$^{8}$ By suspending orders for invalidity, using prospective overruling, and granting conditionally constitutional orders, the Court under Asshiddiqie's leadership preserved a sense of the political branches' primary responsibility for policy.59 Together with the other steps taken, this went some way towards building an understanding of law as an autonomous system of logically ordered norms that has the capacity to constrain both politically partisan and ideologically motivated judicial decision-making.

\footnotetext{
Hendrianto, Law and Politics of Constitutional Courts, 79.

Ibid. (The building was completed in 2007, just one year before Asshiddiqie left office.)

Siregar, Indonesian Constitutional Politics, 99-102.

Ibid, 115 .

Siregar, Indonesian Constitutional Politics, 123; Butt, The Constitutional Court and Democracy, 61.

Butt, The Constitutional Court and Democracy, 67.

Hendrianto, Law and Politics of Constitutional Courts.

5 Ibid, 103-127. The major seeming exception to this cautious approach was the Asshiddiqie Court's Education Budget $V$ decision (Constitutional Court Decision No, 13/PUU-VI/2008) in which the Court ordered compliance with the constitutional requirement that $20 \%$ of the budget be set aside for education.
} 
By the time Asshiddiqie came up for re-election as Chief Justice in 2008, therefore, he had done much to put Indonesia's judicial review regime on a path to consolidation around a version of democratic legalism. The particular version of this regime that the Court was helping to build was one in which its claim to authority would have been contingent on its reputation for impartial enforcement of the ground rules for sound democratic governance. But Asshidiqqie, of course, was not re-elected. For reasons that are hard to establish with certainty, he was defeated in an intra-curial vote for the chief justiceship by Mahfud, a then newly appointed judge who had promised at his nomination hearing to adopt a more deferential approach to the implementation of the Court's mandate. ${ }^{60}$

Much has been written about the Court's change of direction under its second chief justice. ${ }^{61}$ For present purposes, the key point is that Mahfud's accession to the chief justiceship cut across the democratic-legalist understanding of the Court's authority that Asshiddiqie had propounded. This was the consequence not so much of a deliberate change in strategy as the fact that Mahfud had a very different conception of law's authority. Taking shape during his doctoral research at Gadjah Mada University, Mahfud MD's personal judicial philosophy was influenced by two theorizations of law in particular: Nonet and Selznick's idea of "responsive law" and Satjipto Rahardjo's so-called "progressive legal approach" (hukum progresif). ${ }^{62}$ Both these theorizations conceive of law's authority as residing, not in its autonomy from politics, but in its capacity to promote a certain kind of politics: participatory, engaged, and social-justice-seeking.

On his elevation to the Bench, Mahfud began to operationalize this conception in the form of a "substantive justice" approach to decision-

\footnotetext{
Although the chief justiceship was decided by internal judicial vote, there were some suggestions of political influence. See Theunis Roux and Fritz Siregar, "Trajectories of Curial Power: The Rise, Fall and Partial Rehabilitation of the Indonesian Constitutional Court," Australian Journal of Asian Law 16, no. 2, Article 2 (2016): 1, 10.

61 See Hendrianto, Law and Politics of Constitutional Courts; Butt, The Constitutional Court and Democracy; Siregar, Indonesian Constitutional Politics.

62 Phillippe Nonet and Philip Selznick, Toward Responsive Law: Law \& Society in Transition (New Brunswick, NJ: Transaction Publishers, 2001). See Siregar, Indonesian Constitutional Politics, 115; Hendrianto, Law and Politics of Constitutional Courts, 161.
} 
making. ${ }^{63}$ Under his chief justiceship, the Court's opinions became more reliant on broad concepts like justice and fairness as opposed to direct references to constitutional provisions. ${ }^{64}$ Ideologically, too, the Mahfud Court began to articulate a more explicit pro-poor agenda. ${ }^{65}$ As Simon Butt puts it, the Court under Mahfud became "arguably more concerned with resolving immediate political issues and building popularity than with applying or creating legal principles that could be readily applied in future cases" ${ }^{66}$ Its remedial orders at the same time became more intrusive. ${ }^{67}$ If Asshiddiqie's leadership style had been one of "prudential-minimalism", Mahfud was a chief justice in a more traditionally "heroic" mould. ${ }^{68}$ In the conceptual vocabulary developed here, the Court under Mahfud's chief justiceship began to stake out its claim to authority on noticeably more instrumentalist grounds. What mattered was the consequences of the Court's decisions, and whether they were perceived to be just or not.

As should now be clear, this second way of conceiving of law's authority is perfectly valid in the abstract. Other courts have defended their authority in this way and this has proved in certain circumstances to be a basis for stable constitutional governance. There is a question in Indonesia's case, however, about whether the timing of the Court's adoption of such an overtly instrumentalist conception of its authority was right - both because this conception came as such a sudden corrective on the Asshiddiqie Court's approach and because Indonesia's constitutional democracy was still in its infancy.

It is interesting in this respect that Mahfud's views were so strongly influenced by Nonet and Selznick's work. In their book, Toward Responsive Law, these authors distinguish three kinds of legal order - repressive, autonomous and responsive - and express a normative preference for

\footnotetext{
See Siregar, Indonesian Constitutional Politics, 115; Butt, The Constitutional Court and Democracy, 80; Hendrianto, Law and Politics of Constitutional Courts, 167.

64 Butt, The Constitutional Court and Democracy, 63.

65 Hendrianto, Law and Politics of Constitutional Courts, 163.

66 Butt, The Constitutional Court and Democracy, 64.

Ibid, 124.

8 Hendrianto, Law and Politics of Constitutional Courts, 4.
} 
the latter. ${ }^{69}$ They are careful to say, however, that there is no necessary developmental progression between these modes and that there are considerable risks associated with a transition to responsive law..$^{70}$ In particular, because the responsive conception (which is similar to what this paper has been calling an instrumentalist conception) is founded on law's openness to political influence, there is a risk that a deliberate attempt to drive a transition towards it will politicize the judicial process, making it harder for the Court to establish its legitimacy.

Nonet and Selznick's advice is borne out by comparative experience. As we have seen, there are two countries in which a transition to democratic instrumentalism has successfully occurred - the US and India. In both these cases, however, judicial review was firmly established at the time the transition took place. Each country had also enjoyed a long tradition of judicial independence. In the US, the transition to democratic instrumentalism came on the back of profound economic changes and the sustained ideational work done by the legal realist movement. In India, the transition was aided by the damage done to legalism by the Court's performance during the 1975-77 Emergency and the charismatic leadership provided by the post-Emergency justices, Bhagwati and Krishna Iyer JJ. Another crucial factor in India's case was that these two justices had the backing of Prime Minister Indira Gandhi, whose pro-poor political program they were in effect implementing. ${ }^{11}$ In both the US and India, therefore, the risks that Nonet and Selznick talked about were reduced.

The situation was quite different in Indonesia. As noted, Mahfud had been appointed on the back of a promise to adopt a more deferential approach. He consequently lacked the political support that Bhagwati and Krishna Iyer JJ had enjoyed when implementing their pro-poor vision of the Indian Supreme Court's role. Without that kind of political support,

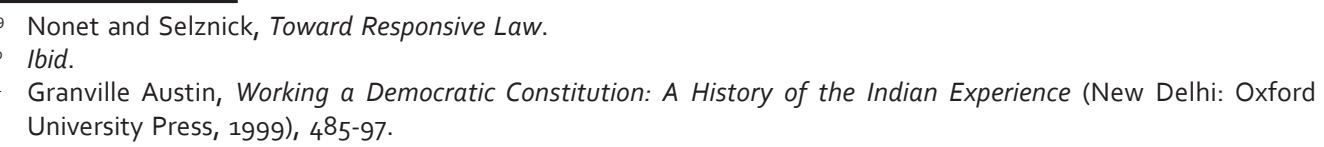


there was a risk that Mahfud's well-intentioned efforts to turn the Court into a forum for promoting substantive justice would be misconstrued as the pursuit of a purely private agenda.

In South Africa, when the American Critical Legal Studies scholar, Karl Klare, recommended that the Constitutional Court should adopt a more openly politicized understanding of its mandate, the Court was appropriately circumspect. ${ }^{72}$ While it did adopt Klare's reading of the 1996 South African Constitution as embodying a commitment to "transformative constitutionalism", it supported that reading in traditionally legalist fashion with references to the constitutional text. In this way, the Court was able to present its decisions as conforming to orthodox understandings of law's authority even as those decisions intruded ever further into the democratic process. ${ }^{73}$ The German Constitutional Court adopted a similarly legalist approach to its understanding of its mandate. ${ }^{74}$

These processes are complex, and the lines of causation are far from clear. But the Mahfud Court's move to a more politicized conception of law, coupled with the greater intrusiveness of its remedial orders when compared to the Asshiddiqie Court, certainly did not help to fortify the Court's position. By abruptly changing the basis for the Court's claim to authority, Mahfud's substantive justice approach arguably exposed it to charges of judicial overreach. In 2011,75 and again in $2013,^{76}$ the Dewan Perwakilan Rakyat (DPR) amended the Court's governing statute in an attempt to return it to its original "negative legislator" mandate. ${ }^{77}$

Over and above their immediate policy rationales, the 2011 and 2013 amendments should be understood as an attempt to redraw the boundary

\footnotetext{
Theunis Roux, "Transformative Constitutionalism and the Best Interpretation of the South African Constitution: A Distinction without a Difference?" Stellenbosch Law Review 20, no. 2 (2009): 258.

73 Theunis Roux, "The South African Constitutional Court's Democratic Rights Jurisprudence: A Response to Samuel Issacharoff," Constitutional Court Review 5 (2014): 33.

74 Michaela Hailbronner, Traditions and Transformations: The Rise of German Constitutionalism (Oxford: Oxford University Press, 2015).

75 Law 8 of 2011.

76 In presidential emergency interim order (PERPU) 1 of 2013 confirmed by Law 4 of 2014.

77 See Simon Butt and Tim Lindsey, The Constitution of Indonesia: A Contextual Analysis (Oxford: Hart Publishing, 2012), 144-146.
} 
between law and politics. As the President and the DPR saw things, the Court had expanded the scope of its authority beyond what had originally been intended. There was no question of judicial review regime change - of anyone seeking a return to authoritarian legalism. Rather, what was being attempted was the contraction of the scope of law's authority along the lines of what occurred in the US in 1937 when the Supreme Court, under the threat of Roosevelt's court-packing plan, relinquished authority over economic legislation. ${ }^{8}$

Understood in these terms, the 2011 and 2013 amendments constituted an important opportunity for the Constitutional Court to try to build a shared understanding of its legitimate role in national politics. This opportunity, however, was not taken up. Instead, the Court struck down many of the 2011 amendments, ${ }^{79}$ depicting the legislation as an attack on its independence. Given that the amendments were in part driven by legitimate concerns about the personal integrity of some of the justices, ${ }^{80}$ this stance appears somewhat dogmatic. From a comparative perspective, at least, the Court's strong defence of its independence was arguably not appropriate to a situation where (a) there were genuine reasons for the political branches to introduce more effective judicial accountability measures; (b) Indonesia's democracy, though still under threat from authoritarian elements, was improving and capable of legitimately expressing the people's desire for such measures. ${ }^{{ }_{1}}$

Something similar happened in 2013, when there was even more reason, given the Akil Mochtar corruption scandal, ${ }^{82}$ for the Court to try to find an accommodation with the political branches. While the Court's striking down

78 Robert G., McCloskey, The American Supreme Court 4th ed revised by Sanford Levinson (Chicago: University of Chicago Press, 2005), 101.

79 Constitutional Court Decision 48/PUU-IX/2011 and Constitutional Court Decision 49/PUU-IX/2011.

80 Stefanus Hendrianto, "The Indonesian Constitutional Court at a Tipping Point," International Journal of Constitutional Law Blog, October 3, 2013, http://www.iconnectblog.com/2013/10/the-indonesian-constitutional-courtat-a=tipping-point.

81 See Owen M. Fiss, "The Right Degree of Independence," in Transition to Democracy in Latin America: The Role of the Judiciary, ed. Irwin P. Stotzky (Boulder, CO, Westview Press, 1992) 55; Stephen Holmes, "Judicial Independence as Ambiguous Reality and Insidious Illusion," in From Liberal Values to Democratic Transition: Essays in Honour of János Kis, ed. Ronald Dworkin (Budapest, Central European University Press, 2004), 3, 9.

82 See Hendrianto, Law and Politics of Constitutional Courts, 196-98. 
of the 2013 amendments again appeared forceful, it was the wrong kind of forcefulness. A Court's legitimate claim to authority in a constitutional democracy, on either a legalist or an instrumentalist conception, comes not from dogmatic defence of its prerogatives, but from its ability to present a defensible account of its role in national politics. It is not clear how the Court's decisions on the 2011 or 2013 amendments did that.

While the Court has recovered from the immediate damage done to its public support by the Mochtar scandal,83 its rather crude defence of its independence in 2011 and 2013 raises questions about the future of Indonesian constitutionalism. To be sure, the Court is still playing an important role in safeguarding democracy - demonstrated, for example, by its decisions on the losing candidate, Prabowo Subianto's challenge to the 2014 presidential election outcome ${ }^{84}$ and the so-called "MD3 law", ${ }^{5}$ which threatened rights to freedom of speech and association. But the Court has on two other occasions avoided taking decisions on democracy-threatening measures. In the first of these, the Court suspended its order of invalidity on the constitutionality of staggered legislative and presidential elections until after the 2014 elections. ${ }^{86}$ In the second, it first rejected a challenge to a $20 \%$ presidential election threshold requirement, ${ }^{87}$ and then delayed deciding a renewed challenge until after the 2019 elections. ${ }^{88}$ These decisions suggest that the Court is less certain than it used to be about its ability to survive a direct confrontation with the political branches. Part of the reason for this, this article has argued, is its equivocation between a legalist and instrumentalist conception of its authority. Until the Court settles

83 Bjoern Dressel and Tomoo Inove, "Megapolitical Cases before the Constitutional Court of Indonesia since 2004: An Empirical Exploration" (unpublished paper presented at the 2nd Indonesian Constitutional Court International Symposium on the "Constitutional Court and Constitutionalism in Political Dynamics," Yogyakarta, 1-3 October 2018).

84 Constitutional Court Decision 1/PHPU.Pres-XII/2014

85 Constitutional Court Decision 16/PUU-XVI/2018.

${ }^{86}$ Constitutional Court Decision 14/PUU-XI/2013.

87 Constitutional Court Decision 53/PUU-XV/2017.

88 Abdurrachman Satrio, "Constitutional Retrogression in Indonesia under President Joko Widodo's Government: What Can the Constitutional Court Do?" (unpublished paper presented at the 2nd Indonesian Constitutional Court International Symposium on the "Constitutional Court and Constitutionalism in Political Dynamics," Yogyakarta, 1-3 October 2018). 
on one or the other of these conceptions (preferably the former, given the problems with instrumentalism in the transitional context), it cannot hope to build a defensible public understanding of its legitimate role in national politics. Instead, its public support will continue to fluctuate with changing public perceptions of the personal moral integrity of the justices and the competence and reliability of other institutions. Whether this will be enough is questionable given the profound challenges facing Indonesia's democracy. ${ }^{89}$ In the circumstances, the Court would do well to re-dedicate itself to the work that Chief Justice Asshiddiqie began. That means paying attention to the technical quality of its decisions, presenting an account of its authority as stemming from the impartiality of its reasoning processes rather than from the justices' personal conceptions of social justice, and engaging in continued efforts to educate the public about the nature of its role in Indonesia's democracy.

\section{CONCLUSION}

This paper presented a comparative framework for understanding the evolution of judicial review regimes and then applied that framework to examine the development of Indonesia's judicial review regime after 2002. It started by relating the well-known story of the transformation of American law that occurred over the first half of the last century. As told by Morton Horwitz and others, that story is about how the premises of Classical Legal Thought were destabilised by the changes to the American economy that occurred in the second half of the nineteenth century, and about how the legal realist movement exploited the ensuing crisis to transform the dominant American conception of the law/politics relationship. Mining that well-known story for generalizable concepts, the paper posited that the two main variables driving constitutional development in systems of strong-form judicial review are societal conceptions of law's claim to authority, on the one hand, and societal conceptions of political

\footnotetext{
89 See Marcus Mietzner, "Fighting Illiberalism with Illiberalism: Islamist Populism and Democratic Deconsolidation in Indonesia," Pacific Affairs 91, no. 2 (2018): 261; Edward Aspinall, "Twenty Years of Indonesian Democracy: How Many More?" http://www.newmandala.org/20-years-reformasi/.
} 
authority, on the other. Each of those variables, the paper argued, is liable to change independently of the other. Under certain conditions, however, they may also lock into each other to form a relatively stable judicial review regime. The paper then set out four ideal-typical such regimes defined by their distinctive combinations of legal and political authority. The fourth section applied this framework to Indonesia, arguing that the Constitutional Court's equivocation between a legalist and instrumentalist conception of its claim to authority has delayed the consolidation of a determinate judicial review regime. The stabilisation of such a regime, the paper concluded, is vitally necessary if the Court is to continue to play an effective role in supporting Indonesia's democracy.

\section{BIBLIOGRAPHY}

Aspinall, Edward. "Twenty Years of Indonesian Democracy: How Many More?” http://www.newmandala.org/2o-years-reformasi/.

Atiyah, Patrick S, and Robert S. Summers. Form and Substance in AngloAmerican Law: A Comparative Study of Legal Reasoning, Legal Theory, and Legal Institutions. Oxford: Clarendon Press, 1987.

Austin, Granville. Working a Democratic Constitution: A History of the Indian Experience. New Delhi: Oxford University Press, 1999.

Bánkuti, Miklós, Gábor Halmai and Kim Lane Scheppele. "Hungary’s Illiberal Turn: Disabling the Constitution." Journal of Democracy 23 no. 3 (2012): $138-46$.

Baxi, Upendra. The Indian Supreme Court and Politics. Lucknow: Eastern Book Co, 1980 .

Bhuwania, Anuj. Courting the People: Public Interest Litigation in Post-Emergency India. Cambridge: Cambridge University Press, 2017.

Butt, Simon. The Constitutional Court and Democracy in Indonesia. Leiden: Brill Nijhoff, 2015. 
Butt, Simon and Tim Lindsey. The Constitution of Indonesia: A Contextual Analysis. Oxford: Hart Publishing, 2012.

Dressel, Bjoern and Tomoo Inoue. "Megapolitical Cases before the Constitutional Court of Indonesia since 2004: An Empirical Exploration." Unpublished paper presented at the and Indonesian Constitutional Court International Symposium on the "Constitutional Court and Constitutionalism in Political Dynamics," Yogyakarta, 1-3 October 2018.

Fiss, Owen M. “The Right Degree of Independence.” In Transition to Democracy in Latin America: The Role of the Judiciary, edited by Irwin P. Stotzky, 5572. Boulder, CO: Westview Press, 1992.

Foulkes, Albert S. "On the German Free Law School (Freirechtsschule)." Archiv für Rechts- und Sozialphilosophie /Archives for Philosophy of Law and Social Philosophy 55, no. 3 (1969): 367-417.

Gibson, James L, and Gregory Caldeira. "Has Legal Realism Damaged the Legitimacy of the U.S. Supreme Court?" Law E Society Review 45, no. 1 (2011): 195-219.

Gillman, Howard. The Constitution Besieged: The Rise and Demise of Lochner Era Police Powers Jurisprudence. Durham, NC: Duke University Press, 1993. Gordon, Robert W. "Legal Thought and Legal Practice in the Age of American Enterprise, 1870-1920." In Professions and Professional Ideologies in America, edited by Gerald L Geison, 70-82. Chapel Hill: University of North Carolina Press, 1983.

Grechenig, Kristoffel and Martin Gelter. "The Transatlantic Divergence in Legal Thought: American Law and Economics vs. German Doctrinalism.” Hastings International and Comparative Law Review 31 no. 1 (2008): 295-360.

Grey, Thomas C. "Langdell's Orthodoxy." University of Pittsburgh Law Review 45 (1983): 1-53.

Hailbronner, Michaela. Traditions and Transformations: The Rise of German Constitutionalism. Oxford: Oxford University Press, 2015.2 
Halliday. Terence C. and Lucien Karpik. "Political Liberalism in the British PostColony: A Theme with Three Variations." In Fates of Political Liberalism in the British Post-Colony: The Politics of the Legal Complex, edited by Terence C. Halliday, Lucien Karpik and Malcolm Feeley, 3-55. Cambridge: Cambridge University Press, 2012.

Hendrianto, Stefanus. "The Indonesian Constitutional Court at a Tipping Point." International Journal of Constitutional Law Blog (October 3, 2013), http:// www.iconnectblog.com/2013/10/the-indonesian-constitutional-court-ata=tipping-point.

Hendrianto, Stefanus. Law and Politics of Constitutional Courts: Indonesia and the Search for Judicial Heroes. London: Routledge, 2018.

Holmes, Stephen. "Judicial Independence as Ambiguous Reality and Insidious Illusion." In From Liberal Values to Democratic Transition: Essays in Honour of János Kis, edited by Ronald Dworkin, 3-12. Budapest: Central European University Press, 2004.

Horowitz, Donald L. Constitutional Change and Democracy in Indonesia. Cambridge: Cambridge University Press, 2013.

Horwitz, Morton J. The Transformation of American Law, 1870-1960: The Crisis of Legal Orthodoxy. New York: Oxford University Press, 1992.

Kennedy, Duncan. “Toward an Historical Understanding of Legal Consciousness: The Case of Classical Legal Thought in America, 1850-1940." Research in Law and Sociology 3 (1980): 3-24.

Kennedy Duncan. A Critique of Adjudication (Fin de Siècle). Cambridge, MA: Harvard University Press, 1997.

Law, David S and Mila Versteeg. "The Evolution and of Global Constitutionalism.” California Law Review 99, no. 5 (2011): 1163-1257.

Lev, Daniel S. "Judicial Authority and the Struggle for an Indonesian Rechtsstaat." Law and Society Review 13, no. 1 (Autumn 1978) 37-71. 
McCloskey, Robert G. The American Supreme Court. 4th ed revised by Sanford Levinson, Chicago: University of Chicago Press, 2005.

Mietzner, Marcus. "How Jokowi Won and Democracy Survived." Journal of Democracy 25, no. 4 (2014): 111-25.

Mietzner, Marcus. "Fighting Illiberalism with Illiberalism: Islamist Populism and Democratic Deconsolidation in Indonesia." Pacific Affairs 91, no. 2 (2018) 261-82.

Moustafa, Tamir and Tom Ginsburg. "Introduction: The Functions of Courts in Authoritarian Politics." in Rule by Law: The Politics of Courts in Authoritarian Regimes, edited by Tom Ginsburg and Tamir Moustafa, 1-22. New York: Cambridge University Press, 2008.

Nonet, Phillippe and Philp Selznick. Toward Responsive Law: Law E Society in Transition. New Brunswick, NJ: Transaction Publishers, 2001.

Pompe, Sebastiaan. The Indonesian Supreme Court: A Study of Institutional Collapse. Ithaca, NY: Cornell Southeast Asia Program Publications, 2005.

Posner, Richard A. "What Has Pragmatism to Offer Law?" Southern California Law Review 63 (1990): 1653-70.

Pound, Roscoe. “Mechanical Jurisprudence.” Columbia Law Review 8 (1908): 605-23.

Rajah, Jothie. Authoritarian Rule of Law: Legislation, Discourse and Legitimacy in Singapore. New York: Cambridge University Press, 2012.

Roux, Theunis. "Transformative Constitutionalism and the Best Interpretation of the South African Constitution: A Distinction without a Difference?" Stellenbosch Law Review 20, no. 2 (2009): 258-85.

Roux, Theunis. "The South African Constitutional Court's Democratic Rights Jurisprudence: A Response to Samuel Issacharoff." Constitutional Court Review 5 (2014): 33-73.

Roux, Theunis. The Politico-Legal Dynamics of Judicial Review: A Comparative Analysis. New York: Cambridge University Press, 2018. 
Roux, Theunis and Fritz Siregar. "Trajectories of Curial Power: The Rise, Fall and Partial Rehabilitation of the Indonesian Constitutional Court." Australian Journal of Asian Law 16, no. 2 Article 2 (2016): 1-21.

Satrio, Abdurrachman. "Constitutional Retrogression in Indonesia under President Joko Widodo's Government: What Can the Constitutional Court Do?" Unpublished paper presented at the 2nd Indonesian Constitutional Court International Symposium on the "Constitutional Court and Constitutionalism in Political Dynamics.” Yogyakarta, 1-3 October 2018.

Schauer, Frederick. "Foreword." In William Twining, Karl Llewellyn and the Realist Movement zed, Cambridge: Cambridge University Press, 2012.

Shapiro, Martin. Courts: A Comparative and Political Analysis. Chicago: University of Chicago Press, 1986.

Siregar, Fritz Edward. "Indonesian Constitutional Politics: 2003-2013.” Doctoral dissertation., UNSW Sydney, 2016.

Summers, Robert S. "Pragmatic Instrumentalism in Twentieth Century American Legal Thought - A Synthesis and Critique of our Dominant General Theory about Law and its Use.” Cornell Law Review Vol 66, (1981): 861-948.

Tamanaha, Brian Z. Beyond the Formalist-Realist Divide: The Role of Politics in Judging. Princeton, NJ: Princeton University Press, 2010.

Trubek, David M. “Complexity and Contradiction in the Legal Order: Balbus and the Challenge of Critical Social Thought about Law/" Law E Society Review 11 (Winter 1977): 529-69.

Tushnet, Mark. Weak Courts, Strong Rights: Judicial Review and Social Welfare Rights in Comparative Constitutional Law. Princeton, NJ: Princeton University Press, 2008.

Weber, Max. Economy and Society Vol 1, edited by Guenther Roth and Claus Wittich. Berkeley: University of California Press, 1968. 